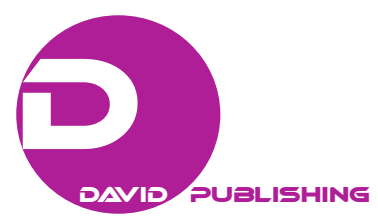

\title{
Rural Tourism and Sustainable Development
}

\author{
Rostom Beridze \\ Batumi Shota Rustaveli State University, Batumi, Georgia
}

\begin{abstract}
The solving of economical and social development problems of rural populated area has particular urgency nowadays. It should be noted that the development of rural tourism is perspective and it gives opportunity to fully use the potential of populated rural area. The objective of research is to study the opportunities of rural tourism development in Georgia and in mountainous region of Adjara. Therefore, the main questions discussed in paper are: to analyze the employment opportunities for the population of rural areas; to foresee the possible secondary income, how to reduce the migration of rural population, especially the youth; possibility to supply the locally produced goods and service and to increase their awareness; and possibilities to develop the industries related to tourism. The joint efforts of government, municipal authorities, and business providers, with the involvement of rural area inhabitants are essential for the development of populated rural territories. The special attention should be addressed to the social initiatives and economic activities of local people through the involvement in the tourism sector development. The rural tourism and entrepreneurship development provide the possibility to solve the main social-economic problems of rural inhabitants.
\end{abstract}

Keywords: rural tourism, sustainable development, tourism policy

\section{Introduction}

Unbalanced development of rural settlement areas is often related to the unequal availability of the territories, increase in rural population migration, insufficient level of social and technical infrastructure development, absence of alternative employment opportunities, and contrast in the level and quality of life between the city and village that finally led to the boost of problems in the rural settlements. As a result, particular importance is given to solve the economic and social development problems of rural settlement areas.

As the following study assumes, rural tourism, concerned with the utilization of natural, cultural, historical, and other resources while developing the tourist product, could be considered as a promising option for the development of rural entrepreneurship and rural settlement areas.

\section{State of Art and Research Methodology}

There have not been carried out thorough studies concerning the stated topic in Georgia. From the studies done abroad, it should be emphasized the following papers: "Rural Tourism and sustainable business" of Hall, Kirkpatrick, and Mitchel (2005), "Competitiveness in Rural US Regions: Learning and Reearch Agenda" of Porter et al. (2004), and "The Next Rural Economies: Constructing Rural Place in a Global Economy" by

Rostom Beridze, professor, Doctor of Economics, Tourism Faculty, Batumi Shota Rustaveli State University, Batumi, Georgia.

Correspondence concerning this article should be addressed to Rostom Beridze, Batumi Shota Rustaveli State University, 6010, 35 Ninoshvili Str. Batumi, Georgia. 
Halseth, Markey, and Bruce (2010). Another important literature related to this topic is "Rural Tourism: An International Perspective" by Dashper (2014).

The research was based on the following principles:

- Focus group interviews. As far as study results, it implies to find out the community perception towards tourism from the different social perspectives. Also, to use mass surveying method.

- General descriptive and correlative approach is used to analyse the survey results and find out the relationship between the variables. Quantitative analyse is essential to find out and show in dynamic the population perception changes in the long term.

\section{Discussion}

Agriculture is a primary business and source of income for the population of mountainous part of Adjara region. Even though, majority of them own only few resources assigned for agricultural work, almost all of them have land devoted to agriculture and produce different cultivated products. The beef, milk, cheese, and honey are the leading sold products. But only 7 percent of families produce the stated products.

The research shows that local community ( $28 \%$ of surveyed population) gets their basic income from realization of livestock and poultry products, compiling the mean of 535 GEL (Georgian Lari) annually. The income from this source is the highest in Khulo municipality reaching 1,005 GEL, and the lowest in Keda municipality-174 GEL.

The other agricultural products represent the source of income for more than one third of survey respondents. The mean equaled to 529 GEL for the last year. The highest annual income-910 GEL was stated in Keda municipality and the lowest is 81 GEL in Shuakhevi.

The income of local community from renting or selling the property, or international money transfers is not high and equals to $1-3 \%$.

The source of income for families is the regular earnings (salary) of family members, represented with 3,194 GEL.

Agriculture is the primary business for the populated areas in the mountainous part of Adjara region. Choosing an agriculture industry, as an enterprise direction, is related to the relief characteristics, soil type, and natural resources. Regarding the other types of enterprise fields - food and beverage establishments, guesthouses, and autoservice, high demand leads to choosing them. The competition is low in the indicated areas and the received income is high.

There are different government programmes promoting rural development in the country, but not all of them are implemented successfully, mainly because of several reasons: The farmers' interests and local relief characteristics are not foreseen and lack of project management; farmers' awareness of projects are low.

The rural tourism is the most perspective industry in the populated settlements of mountainous Adjara region.

It should be noted that rural tourism development has highly promising outlook and gives the opportunity to fully benefit from the potential of rural populated areas. Rural tourism development is related to meet some important challenges:

- To improve state policy of rural tourism development.

- To form the legislation, standards, and norms regulating the rural tourism development.

- To develop the qualified staff training system for the employees of rural tourism. 
- To create the competitive tourist product and promote them on tourism service market.

- To develop the social, transportations and engineering infrastructure, etc.

Analyzing the study leads to formulate the following solutions of the existing problems:

- To create a concept of rural tourism development reflecting the local and national characteristics.

- To form a normative-legislative basis of rural tourism.

- To create tourist products and offer them to different segment markets (individual, family, and small groups).

- To create a marketing strategy for promoting a regional touristic potential in the domestic and international markets.

- To popularize the historical, cultural, and natural sightseeings.

- To increase an awareness of the tourism service market.

- To attract the investments in the tourism industry through the government and private partnerships.

- To create a human resource qualification improving system in the tourism industry.

- To train and encourage the rural youth to create the guesthouses in the frames of "Produce in Georgia" program.

- To create an outstanding rural tourism market in the internet using the contemporary informational technologies.

- To provide a marketing support and promotional activities for the regional touristic products.

\section{Conclusion}

All things considered, the rural tourism development will be beneficial to meet the primary social and economical objectives of the rural settlements:

- To provide the employment of rural population.

- To provide the secondary income.

- To reduce the migration of rural population, especially the youth.

- To supply the locally produced goods and service and to increase their awareness.

- To increase the tourist flows by offering the competitive tourist products in the rural settlement areas.

- To develop the industries related to tourism.

- To restore the cultural heritage sites.

- To preserve the national traditions, customs, and craft.

The joint effort of government, municipal institutions, and business, with the active involvement of rural population is essential in order to ensure the sustainable development of rural settlement areas. Particular attention should be addressed to the social initiatives and economical activities of local communities as part of involvement in tourism industry development.

The rural tourism and entrepreneurship development provides the opportunity to solve the primary social-economical problems of rural communities.

\section{References}

Abesadze, T. (2017). Norwegian experience in the creation of exclusive rural tourism products. Proceedings of International Scientific-Practical Conference-Tourism: Economics and Business, 10-11 June, Batumi, Georgia.

Dashper, K. (2014). Rural tourism: An international perspective. Cambridge: Cambridge Scholars Publishing.

Hall, D., Kirkpatrick, I., \& Mitchel, M. (2005). Rural tourism and sustainable business. Bristol, UK: Channel View Publications. 
Halseth, G., Markey, S., \& Bruce, D. (2010). The next rural economies: Constructing rural place in a global economy. Oxfordshire, UK: CABI International.

Japaridze, D. (2017). Village of the future-Enhancing the competitiveness by promoting tourism and small business (Satsire, Georgia). Proceedings of International Scientific-Practical Conference-Tourism: Economics and Business, 10-11 June, Batumi, Georgia.

Porter, M. E., Ketels, C. H. M., Miller, K., \& Bryden, R. (2004). Competitiveness in rural US regions: Learning and research agenda. Retrieved from https://pdfs.semanticscholar.org/6045/de890b82a8ac5d29ecc949a5750b362aa45e.pdf 